The Geographical Journal of Nepal

Vol. 11: 25-44, 2018

Central Department of Geography,

Tribhuvan University, Kathmandu, Nepal

\title{
Open space: Typology and distribution in Pokhara Lekhnath metropolitan city
}

\author{
Ramjee Prasad Pokharel ${ }^{1 *}$; and Narendra Raj Khanal ${ }^{2}$ \\ ${ }^{1}$ Department of Geography, Prithvi Narayan Campus, Pokhara (Tribhuvan University) \\ Nepal; ${ }^{2}$ Central Department of Geography, Tribhuvan University, Kathmandu, Nepal
}

(*Corresponding Author: ramjeepp@gmail.com)

Open space is essential part of city life because it provides an opportunity for recreation, playing, religious activities, political activities, cultural activities and so on. This paper discusses the types of open space and its distribution in Pokhara Lekhanath Metropolitan City (PLMC). An inventory of open spaces was prepared based on the available analog maps with intensive field verification. There are eight major and 32 subtypes of open spaces with a total number of 246 within the PLMC. The main types of open spaces are park, playground, religious site, water surface, cave, aesthetic view point, river strip and messy places. Those open spaces vary in form, size, ownership and functions. The distribution of open spaces is not uniform among the 33 Wards in the Pokhara Lekhanath Metropolitan City. The number of open space varies from only one to twenty-one and total area of open space varies from only 51 ha to 4786 ha among those Wards. Per capita area of open space ranges from 0.16 to $659 \mathrm{~m}^{2}$ among those wards. In many wards, per capita area of open space is less than $9 \mathrm{~m}^{2}$ which is recommended by FAO. Such a poor situation is created mainly due to the lack of public land use planning, encroachment in open space for development of infrastructure such as public buildings, and lack of knowledge about the importance of open spaces among decision makers and local people and weak capacity of local people to protect and conserve open space from encroachment.

Keywords: Open space; typology; recreation; parks; playgrounds; religious site; cave; aesthetic view point 


\section{Introduction}

Open space is physically defined as a land and water that is not covered by buildings, situated within the urban area (Gold, 1980; Crange, 1982). Open spaces are places in the city where cultural diversity intermingled with natural process and conserve memory (Ward Thompson, 2002). Urban open space is that place which is open to sky (Goettsch, 2015). Similarly, public open space is defined as open space, both green spaces and hard 'civic' spaces to which there is public access (Carmona, 2003). The accessibility is basic element of open space. Accessibility can be identified by statutory access, physical access and mental or psychological access (Staeheli and Mitchell, 2008). It also refers to public access with its legality and road access, time, distance and cost.

Typology is the study of existing elements which cannot be further reduced (Sandlack and Uribe, 2010). Open spaces are classified based on theory of classification and their combination. This is used to describe a group of objects according to the similarity of form and structure (Wang, et al; 2005). Moore (1996) attempted to develop open space typologies in modern urban areas. ILAM (1996) has classified the open spaces based on the types of land use and cultural and visual features. Lynch (1981) developed a typology to categorize open space such as square, plaza, adventure places, playground, and wetland. Carr and others (1992) made a list of open space typology in twelve main types and further subdivided it into 24 categories in western European cities. Similarly, Woolley (2003) prepared an open space typology of nine main categories and $22 \mathrm{sub}$ categories. Stanley, et al., (2007) delineated seven types of open spaces on the basis with mix of form, function, scale and land cover in the modern urban area. Similarly, Carmon (2012) has classified twenty types of open spaces within four typologies.

Urban open spaces are important part of the urban landscape with its specific function. It contributes the quality of urban life (Burke and Evans, 1999). It has different functions. Open spaces are also important for disaster risk management. It is often used temporarily as the place of shelter during the disasters such as earthquake, flood, landslides etc. Though open spaces are very important elements particularly in urban areas, but information about the number, size, location, function and processes of change in open space is scanty. It is in this context that this study on open spaces in Pokhara Lekhanath Metropolitan City (PLMC) was proposed. This paper discusses the typology of public open space, their use, distribution and its management situation in PLMC.

\section{Study area}

PLMC is geographically the largest metropolitan city of Nepal (in terms of administrative boundary) and it is the center of the western part of Nepal, the headquarters 
of Kaski district as well as the capital of province number 4 according to recent federal restructuring of Nepal. The elevation ranges from $505 \mathrm{~m}$ (Kotre) to $2650 \mathrm{~m}$ (Armala) above sea level. The total area of PLMC is $464.94 \mathrm{~km}^{2}$ and which represents 23.01 percent area of the Kaski district and 0.31 percent area of the country. The average temperature in PLMC ranges from $7^{\circ} \mathrm{c}$ minimum to $31^{\circ} \mathrm{c}$ with an annual rainfall of 3800 $\mathrm{mm}$. Pokhara Lekhnath lies within mid hill of western Nepal. This city is situated on the lap of Annapurna Himalayan Range. It is surrounded by green hills. There are 9 lakes, 10 caves, Seti river gorges, several holy places, aesthetic viewpoints which are playing vital role to make city gregarious. This metropolitan has 81456 households and 402995 populations (CBS, 2011). It is divided into 33 wards (Figure 1). PLMC is also known as a multi-cultural city. It is also the most popular tourist destination of Nepal. The number of tourists visiting PLMC has been increasing from 230,000 in 2010 to 301, 200 tourists in 2016 (DOT). Similarly, the growth of domestic tourists visiting PLMC is also in increasing trend. Historically, PLMC had many open spaces with considerable size.

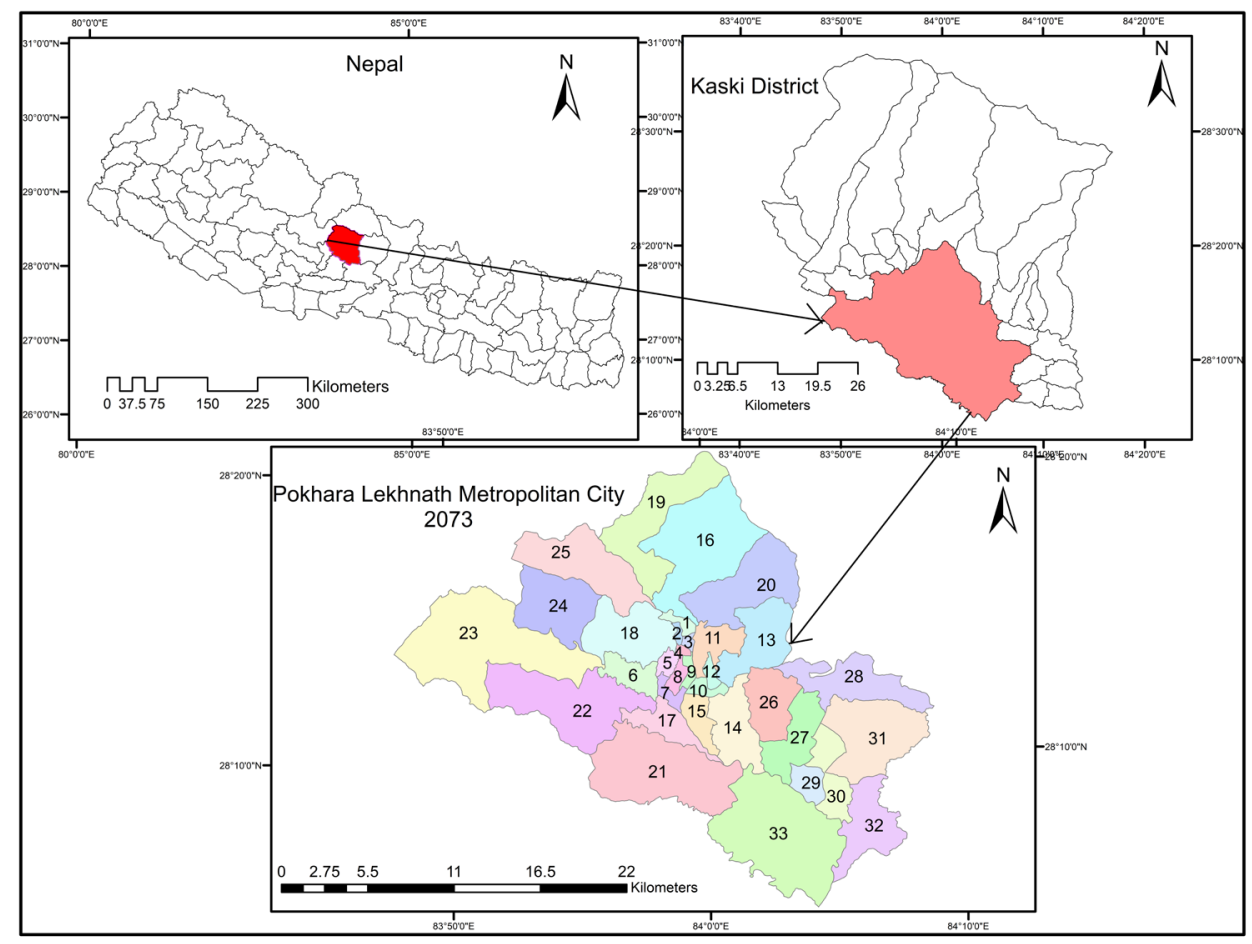

Figure 1: Location Map of Study Area 
Until five decades ago, there were 26 plots of big open space called Chaur and Patan. Lamchaur, Batulchur, Simalchur, Bhimkali Patan, Malepatan, Bajhapatan, Lampatan, Gairapatan, Chhorepatan, Kolpatan, Phalepatan, Gharipatan, Majheripatan, Dhungepatan are some of the famous Patan in PLMC (Adhikari, 2004). By now, large areas of these Chaurs and Patans have been changed into built up areas.

\section{Approaches and methods}

Two approaches have been adopted while collecting and analysing the data. Those are inventory and classification. First of all, a reconnaissance survey was carried out in order to locate open spaces, understand their evolution processes and utilization. Based on experience from reconnaissance survey, a structured questionnaire was prepared. The questionnaire consisted questions regarding the location, size, ownership, accessibility for public use and connectivity with roads, infrastructure development, utilization and management of open space. The field work for data collection was carried out from August 2017 to October 2017 in two phases.

Recently elected Chairpersons of the respective ward office were requested to fill the form and return the completed form with signature and official stamp. After compiling the information obtained from the Chairpersons of all the wards, all the open spaces were visited with the help of local resource person for ground truthing. While visiting the place, locational information was generated with the help of the GPS (Global Positioning System). After having locational information those were plotted and overlaid into Google image (Landsat/Copernicus dated 12/14/2015) in order to prepare the polygons of open space. After preparing the polygon map, it was imported into GIS platform. ArcGIS 10.3 version was used to determine the area of each open space. In addition to these, relevant information was collected from secondary sources such as topographical map (1998), research articles, books, unpublished dissertations.

A scheme of classification of open space was developed with slight modification of the schemes proposed by Carr et al., (1992), Wolley (2003), and Addas (2015) considering the local situation of PLMC (Figure 2). 


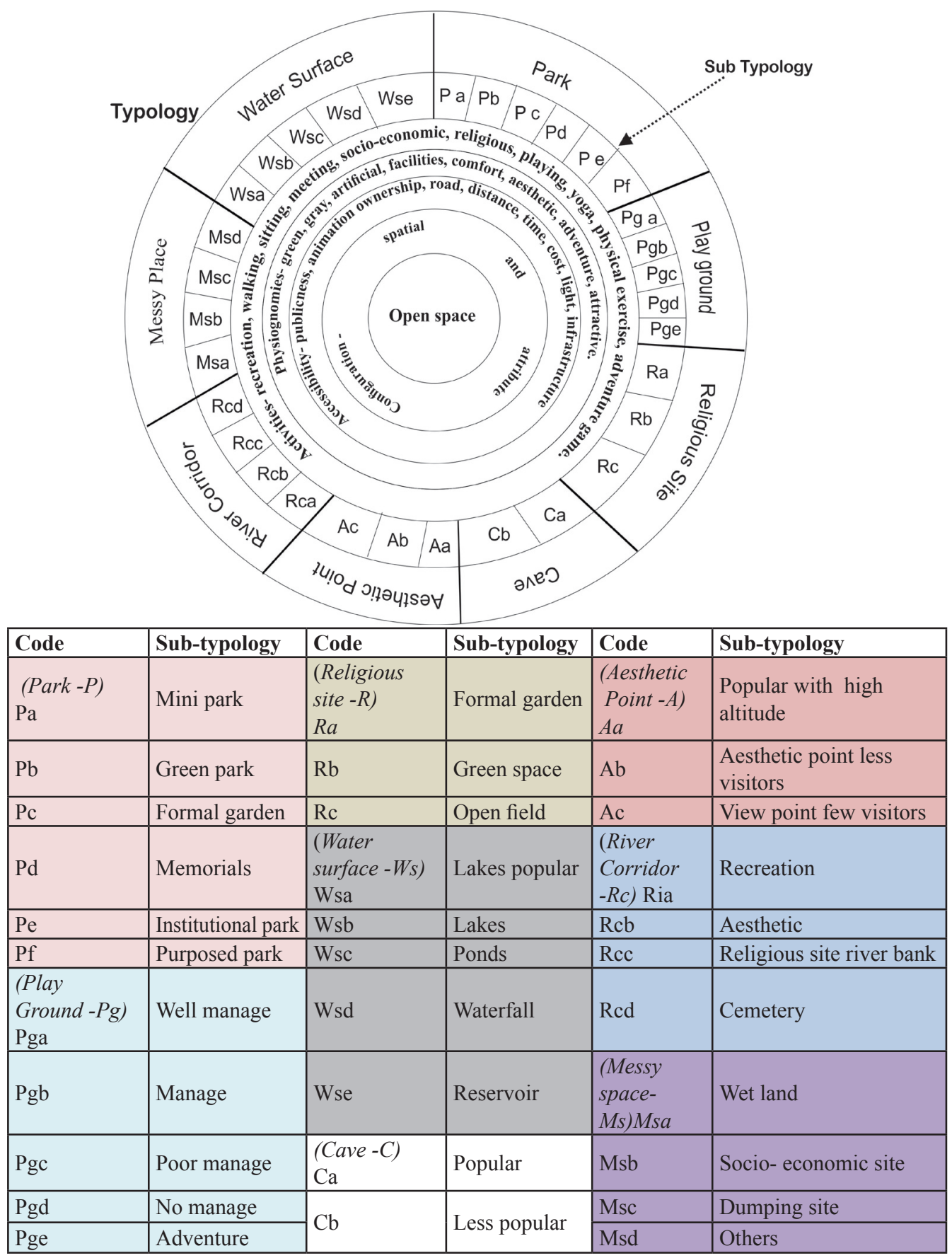

Figure 2- Typology of open space in Pokhata Lekhnath Metropolitan City, 2074.

Source: Adapted form Carr et al., 1992. Woolley 2003; Addas, 2015 with slight modification. 


\section{Result and discussion}

\section{Number and types of open spaces}

A total of 246 open spaces have been identified in the PLMC and the area of patches ranges from 0.0109 hectare to 4340.89 hectare. The number and the percentage of open space with their characteristics in terms of location, accessibility, ownership, and naturalness are given in Table 1. Nearly 58 percent of the total open spaces in the PLMC are located in the valley, 95 percent are accessible for all the time, 83 percent have access from the road, 93 percent are owned by the government, and 54 percent are of grey space without vegetative cover.

Table 1: Type of open spaces

\begin{tabular}{|l|l|r|r|}
\hline \multirow{2}{*}{ Criterion } & \multicolumn{1}{|c|}{$\begin{array}{c}\text { Configuration of open } \\
\text { space }\end{array}$} & Total number & Percent \\
\hline \multirow{2}{*}{ Landscape } & Plain & 142 & 57.72 \\
\cline { 2 - 4 } & Sloppy & 104 & 42.28 \\
\hline \multirow{2}{*}{ Public accessibility } & All time & 233 & 94.72 \\
\cline { 2 - 4 } & No accessible & 13 & 5.28 \\
\hline \multirow{2}{*}{ Road access } & Yes & 204 & 82.93 \\
\cline { 2 - 4 } & No & 42 & 17.07 \\
\hline \multirow{2}{*}{ Owner } & Government & 230 & 93.50 \\
\cline { 2 - 4 } & Community \& Institution & 16 & 6.50 \\
\hline \multirow{2}{*}{ Naturalness } & Cover by vegetation & 89 & 37.40 \\
\cline { 2 - 4 } & Gray space & 157 & 54.47 \\
\cline { 2 - 4 } & Water surface & 20 & 8.13 \\
\hline
\end{tabular}

Source: Field survey 2017

The open spaces in the PLMC are classified into eight-major types in terms of their attributes, function and use. Those are parks, playground, religious sites, water surface, aesthetic place, cave, river strips, and messy spaces (Table 2). The number and a brief description of their characteristics in the PLMC are given in Annex 1. 
Table 2: Open space typology and their attributes;

\begin{tabular}{|c|c|c|c|c|c|c|c|c|c|}
\hline & 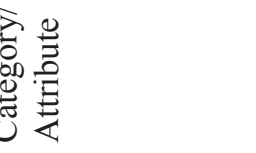 & $\frac{n}{i=}$ & 离 & 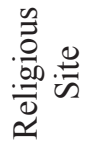 & 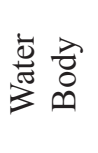 & 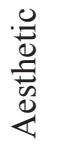 & 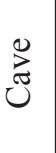 & 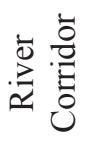 & 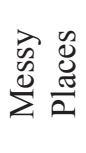 \\
\hline \multirow{4}{*}{ Size (ha) } & Tiny $(<1)$ & 57 & 15 & 48 & 12 & 15 & 8 & 0 & 5 \\
\hline & Small (1-10) & 33 & 10 & 14 & 3 & 3 & 2 & 0 & 6 \\
\hline & Medium (10-50) & 3 & 1 & 0 & 2 & 0 & 0 & 0 & 2 \\
\hline & Large $(>50)$ & 2 & 0 & 0 & 3 & 0 & 0 & $1 *$ & 1 \\
\hline \multirow{2}{*}{ Public Access } & Open & 91 & 26 & 60 & 19 & 17 & 10 & 1 & 7 \\
\hline & Closed & 4 & 0 & 2 & 1 & 1 & 0 & 0 & 7 \\
\hline \multirow{2}{*}{$\begin{array}{l}\text { Ownership/ } \\
\text { Management }\end{array}$} & Government & 82 & 24 & 62 & 20 & 18 & 10 & 1 & 14 \\
\hline & Public & 13 & 2 & 0 & 0 & 0 & 0 & 0 & 0 \\
\hline \multirow[t]{2}{*}{$\begin{array}{l}\text { Management } \\
\text { Quality }\end{array}$} & Well managed & 44 & 2 & 42 & 5 & 5 & 3 & 0 & 2 \\
\hline & Poorly managed & 51 & 9 & 20 & 15 & 13 & 7 & 1 & 12 \\
\hline \multirow{3}{*}{ Popularity } & Highly popular & 18 & 9 & 9 & 5 & 1 & 3 & 1 & 4 \\
\hline & Popular & 30 & 10 & 38 & 6 & 4 & 2 & 0 & 6 \\
\hline & Les popular & 47 & 7 & 15 & 9 & 13 & 5 & 0 & 4 \\
\hline \multirow{2}{*}{ Environment } & Clean & 82 & 21 & 62 & 7 & 12 & 3 & 1 & 5 \\
\hline & Not clean & 13 & 5 & 0 & 13 & 6 & 7 & 0 & 9 \\
\hline $\begin{array}{ll}\text { Promise } & \text { for } \\
\text { future use } & \end{array}$ & \multicolumn{9}{|c|}{$\begin{array}{l}\text { Recreation, aesthetic view point, yoga, playground, religious site, cultural } \\
\text { and peace place, leisure time use, geological information, socio-economic } \\
\text { activities, political activities, tourism promotion site, social wellbeing site, } \\
\text { metal wellbeing site, etc. }\end{array}$} \\
\hline
\end{tabular}

Source: Field survey 2017.

A brief description of major open spaces is given below.

\section{Park}

Park is a public place, where people meet and interact with each other, walk together, and use for social as well as private wellbeing. It provides several opportunities for the people of all age, gender, class, and religious groups. It is a place for active recreation and passive experiences with visual aesthetic resources. World Botanical Garden, Jayakot, Shantiban, Basudhara Park, Komaghane Park, martyr's parks, Puspalal park, Ganeshman park, Phewa dam park, etc. are major as well as famous parks found in PLMC.

\section{Playground}

Playground is a vital part of urban area which provides opportunities to carry out physical exercise for children and youth. Existing institutional playgrounds are not permitted 
for public use. Available public access open field are used for different games. It is a place of recreation, physical wellbeing and occasionally it is used for socio-economic activities and gathering of people for political discussion. In PLMC there are 26 public access playgrounds. Pokhara Stadium, Bhandardhik, Saharapaly, Tundikhel, Malepatan, are major playgrounds. Among them Pokhara stadium is the largest in size and is used for various games and athletics.

\section{Religious site}

Mankind has always wanted to imitate the divine power in the physical world (Michell, 1994) thus they try to obtain the god by pilgrimages (Popi et al., 2012). Religious places are hobs of culture and civilization too. Bhadrakali, Bindabasini, Kedareswor, Matepani Gumba, Galeswor Shivalaya, Shanti Stupa, Harihar temple, Gita temple, Akala temple, are famous religious sites in PLMC.

\section{Water surface}

Water is a unique material for landscaping (Burmill et al., 1999). Water presents its aesthetic beauty to human beings generously (Campbell, 1978). It plays vital role for attraction of people. Pokhara is known as city of lakes because it has almost a dozen of lakes and several artificial ponds which are famous as recreational sites. Phewa, Begnas, Rupa are major lakes. Among them Phewa and Begnas are the most popular destination for visitors. There are some ponds basically around urban periphery.

\section{Aesthetic points}

The aesthetic value of an object is the value it possesses in virtue of its capacity to provide aesthetic gratification (Monroe, 1982). Attributes such as diversity, complexity, contrast, and variety are identified in the literature, either as formal or cognitive factors that contribute to an aesthetic experience (Ulrich, 1981). Aesthetic point gives an opportunity for pleasure. There are many sites with the panoramic view of snowcapped mountains, lakes and surrounding greenery hill in PLMC. The amazing view can be seen from these sites. Among them Sarankot, Kahun Danda, Phoksing hill, Mattikhan hill, Hundi Kot, Budha Kot, Sundari Danada are famous points. Sarangkot is the most famous for viewing Pokhara valley and close view of Macchapuchhre and Annapurna Himal.

\section{Cave}

Cave is often decorative by speleothems and it has significant recreational value. This is also the site for the establishment of religious temple which attracts millions of tourists due to its scenic environment (Hamilton, 1997). Caves are interesting geomorphological 
feature. There are several mysterious caves in PLMC. The major ones are Mahendra, Gupteswor, Birendra, Kaur, Gagham, Bat caves. Some caves are long while others are quite short. Most of the caves have only one opening for its entry and exit but Gupteshwor cave is an exception with both sides opening. Mahendra, Gupteswor and Bat caves are very popular ones.

\section{River strip}

Most of the cities have been developed along river. The configuration of rivers usually results in their being equivalent to linear parks (Silva, 2004). A river strip (corridor) includes the width of the channel in which water flows and is typically expanded to account for the extensive influence of the watercourse into the surrounding landscape. Pokhara city is developed along the Seti, Bijayapur and Phusre rivers. Seti river has diverse morphology - steep cliff with deep gorges and opening with terraces. Some sites of river bank such as Ramghat, Tulasighat, Gaighat, Sitapailaghat, Dovillaghat, are used for bathing purpose during the festivals and rituals cenremonies. Similarly, some sites of Seti river bank like Ramghat, Tulasighat, Gaighat, Sitapailaghat, Dovillaghat are used for cemetery. Bachhi Buduwa located in ward no 14 of PLCM is the main dumping site.

\section{Messy open spaces}

Massy open space includes all the areas with public, community and private ownership. These sites are not allowed to use for all as a public open space. For example, airport seem open but people can't amend it as a recreation place. Similarly, the areas used for government offices, schoolyards, hospitals, armed force yard are also seen as an open space but people do not have cognitive perception as public open space due to their inaccessibility. There are four types of messy open spaces in PLMC. Those are wetland (Phewa, Gunde, Rupa etc), sites important from socio-economic point of view such as exhibition centre, dumping site and others recreation area such as Matgaunda, Phewa Powerhouse, Begnas lake side, etc.

\section{Distribution of open space}

Table 3 shows ward-wise distribution of open spaces in PLMC. The number of open space ranged from only one to 21 among the 33 wards in PLMC (Figure 3). The area ranges of patches ranges from 0.0109 hectare to 4340.89 hectare. The space available among those wards ranges from $0.45 \mathrm{~m}^{2}$ to $628.73 \mathrm{~m}^{2}$ with the average per capita open space of $55.49 \mathrm{~m}^{2}$. The United Nations Food and Agriculture Organization (FAO) has recommended $9 \mathrm{~m}^{2}$ of open space per city dwellers as the minimum value requirement (Kuchelmeister, 1998). With this standard, ward no 1, 2, 3, 5, 7, 8, and 12 have less than this standard minimum value requirement of per capita area of open spaces. Wang and 
others (2013) reported that per capita area of open space in developed countries is about $20 \mathrm{~m}^{2}$. In PLMC out of 33 wards, 13 wards have per capita open space less than $20 \mathrm{~m}^{2}$.

Table 3: Ward-wise distribution of open spaces

\begin{tabular}{|c|c|c|c|c|c|c|c|}
\hline $\begin{array}{c}\text { PLMC } \\
\text { Ward }\end{array}$ & $\begin{array}{l}\text { Patches } \\
\text { Number } \\
\text { of open } \\
\text { spaces }\end{array}$ & $\begin{array}{l}\text { Ward area } \\
\text { (hectare) }\end{array}$ & $\begin{array}{c}\text { Open } \\
\text { space Area } \\
\text { (hectares) }\end{array}$ & Population & $\begin{array}{c}\text { Ward area } \\
\text { in Hector/ } \\
\text { per } 1000 \\
\text { Population }\end{array}$ & $\begin{array}{l}\text { Open space } \\
\text { area in Hector/ } \\
\text { per } 1000 \\
\text { Population }\end{array}$ & $\begin{array}{l}\text { Per } \\
\text { capita } \\
\text { open } \\
\text { space } \\
\left(\mathrm{m}^{2}\right)\end{array}$ \\
\hline 1 & 5 & 154.54 & 13.85 & 15513 & 9.96 & 0.89 & 8.93 \\
\hline 2 & 3 & 60.14 & 1.48 & 8729 & 6.89 & 0.17 & 1.69 \\
\hline 3 & 6 & 63.49 & 6.26 & 9462 & 6.71 & 0.66 & 6.62 \\
\hline 4 & 1 & 51.05 & 0.41 & 9119 & 5.60 & 0.04 & 0.45 \\
\hline 5 & 4 & 178.42 & 2.37 & 14803 & 12.05 & 0.16 & 1.60 \\
\hline 6 & 10 & 633.48 & 448.72 & 14729 & 43.01 & 30.47 & 304.65 \\
\hline 7 & 7 & 197.59 & 2.95 & 12875 & 15.35 & 0.23 & 2.29 \\
\hline 8 & 4 & 176.49 & 0.42 & 26080 & 6.77 & 0.02 & 0.16 \\
\hline 9 & 2 & 122.46 & 17.97 & 16626 & 7.37 & 1.08 & 10.81 \\
\hline 10 & 6 & 195.84 & 29.60 & 18470 & 10.60 & 1.60 & 16.02 \\
\hline 11 & 9 & 697.89 & 29.35 & 14716 & 47.42 & 1.99 & 19.94 \\
\hline 12 & 3 & 140.13 & 3.17 & 11613 & 12.07 & 0.27 & 2.73 \\
\hline 13 & 12 & 1540.12 & 85.60 & 17077 & 90.19 & 5.01 & 50.12 \\
\hline 14 & 10 & 1338.47 & 39.20 & 13225 & 101.21 & 2.96 & 29.64 \\
\hline 15 & 11 & 512.61 & 73.01 & 17027 & 30.11 & 4.29 & 42.88 \\
\hline 16 & 7 & 3473.7 & 30.18 & 20278 & 171.30 & 1.49 & 14.88 \\
\hline 17 & 21 & 790.11 & 66.90 & 26752 & 29.53 & 2.50 & 25.01 \\
\hline 18 & 5 & 1779.24 & 86.97 & 8354 & 212.98 & 10.41 & 104.11 \\
\hline 19 & 14 & 2456.67 & 49.74 & 10624 & 231.24 & 4.68 & 46.82 \\
\hline 20 & 8 & 2297.73 & 14.48 & 4022 & 571.29 & 3.60 & 35.99 \\
\hline 21 & 14 & 3595.72 & 53.60 & 9090 & 395.57 & 5.90 & 58.96 \\
\hline 22 & 9 & 3215.21 & 219.12 & 7391 & 435.02 & 29.65 & 296.47 \\
\hline 23 & 8 & 4786.05 & 166.30 & 4917 & 973.37 & 33.82 & 338.21 \\
\hline 24 & 12 & 1852.67 & 37.79 & 5892 & 314.44 & 6.41 & 64.14 \\
\hline 25 & 10 & 2241.59 & 33.17 & 12262 & 182.81 & 2.71 & 27.05 \\
\hline 26 & 4 & 1215.37 & 38.73 & 11394 & 106.67 & 3.40 & 33.99 \\
\hline 27 & 5 & 1225.02 & 31.43 & 9583 & 127.83 & 3.28 & 32.80 \\
\hline 28 & 7 & 1760.46 & 6.24 & 4727 & 372.43 & 1.32 & 13.20 \\
\hline 29 & 6 & 422.42 & 22.16 & 8961 & 47.14 & 2.47 & 24.73 \\
\hline 30 & 3 & 941.74 & 22.68 & 10823 & 87.01 & 2.10 & 20.96 \\
\hline 31 & 7 & 2450.23 & 486.01 & 7378 & 332.10 & 65.87 & 658.73 \\
\hline 32 & 3 & 1503.19 & 22.10 & 10677 & 140.79 & 2.07 & 20.70 \\
\hline 33 & 9 & 4425.15 & 94.09 & 9806 & 451.27 & 9.60 & 95.95 \\
\hline Total & $245+1$ & 46494.99 & 2236.04 & 402995 & 115.37 & 5.55 & 55.49 \\
\hline
\end{tabular}

Note: +1 refers River Corridor

Source: CBS 2011 and field survey, 2017. 


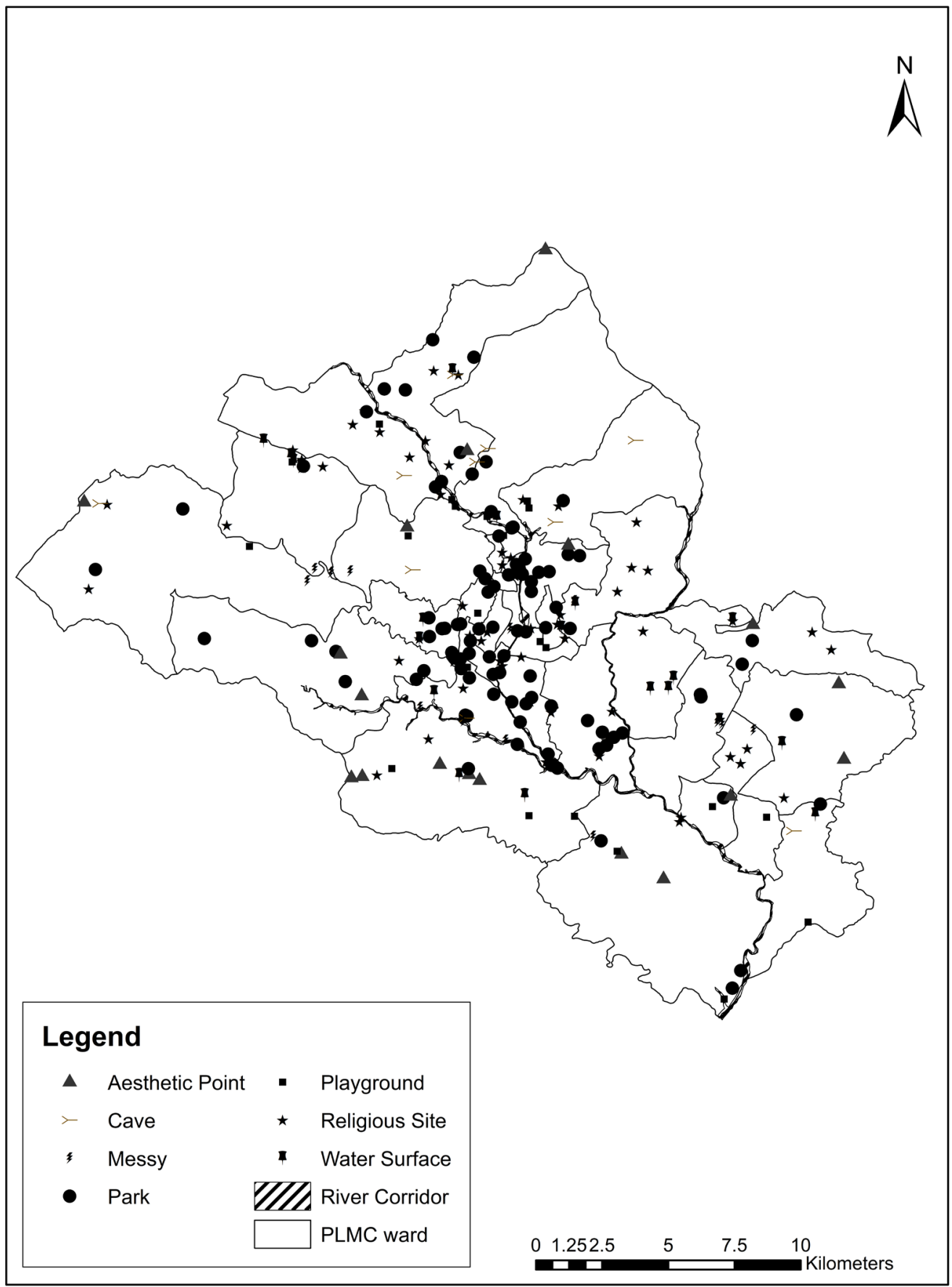

Figure 3- Spatial Distribution of open spaces in PLMC, 2017 
Such an uneven distribution of open spaces among the wards in PLMC is due to the lack of public land use planning, encroachment in open space for development of infrastructure such as public buildings, and lack of knowledge about the importance of open spaces among decision makers and local people and weak capacity of local people to protect open space from encroachment.

\section{Management of open space}

Management is primary concern to make open space attractive and sustainable urban environment. Different types of open spaces require different types of management modalities. Generally, management activities for open spaces includes the construction for fencing, and the construction of sheds, footpath, sitting place, security areas, rest room, road, parking area, repair-maintenance, entry-exit management. In PLMC, only 44 percent open spaces have been found as managed open spaces with essential infrastructures (Figure 4). The remaining 56 percent sites do not have such infrastructure and they are not managed properly. Others are remaining in natural state.

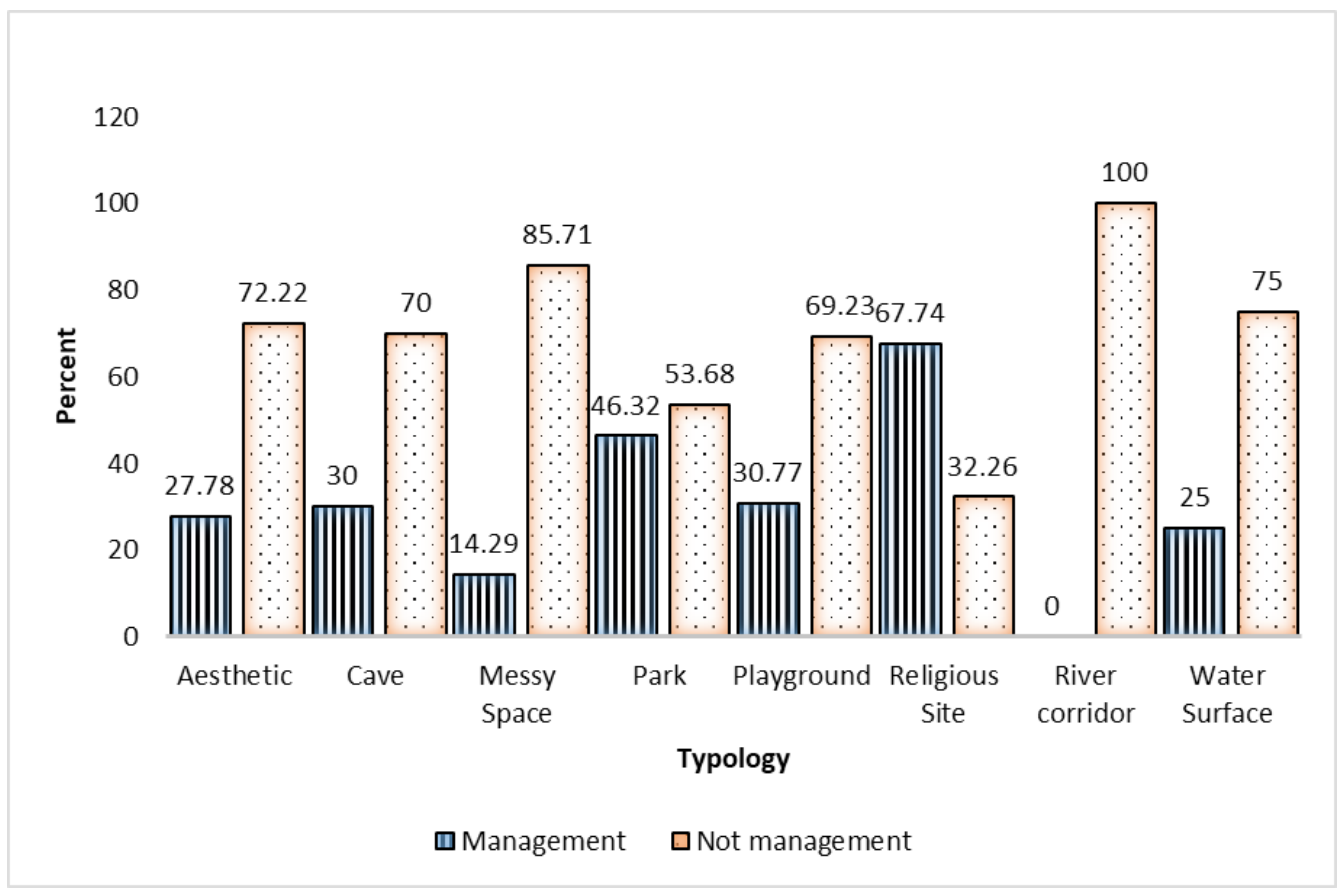

Figure 4: Percent of open space with the level of management 
Figure 4 shows only 28 percent of aesthetic sites are managed whereas the remaining 72 percent sites are without any infrastructure. Similarly, 30 percent caves of PLMC are managed for visitors' purpose. Similarly, only 31 percent of the playgrounds are under proper management and also 68 percent of the total religious spaces are under well managed state. Water surface and messy spaces are less managed.

\section{Conclusion}

Open space is an inseparable part of urbanities. Open space is a place for havingrecreation, cognitive pleasure and carrying out, physical activities, social interaction, socioeconomic activities, religious activities, and it also helps in beautification of the city.

The PLMC historically had many large areas of open spaces which are known as Chaur and Patan. But with the rapid urbanization and growth of infrastructure including private and public buildings, the areas of open space have been decreased drastically. At present, there are eight major and 32 subtypes of open spaces with a total number of 246 within the PLMC. The main types of open spaces are park, playground, religious site, water surface, cave, aesthetic view point, river strip and messy places. Those open spaces vary in form, size, ownership and functions.

Open spaces are unevenly distributed and in many wards, per capita area of open space is less than the values recommended by FAO and per capita open space reported from developed countries. Such a poor situation is created mainly due to the lack of public land use planning, encroachment in open space for development of infrastructure such as public buildings, and lack of knowledge about the importance of open spaces among decision makers and local people and weak capacity of local people to protect open space from encroachment.

Many open spaces in PLMC do not have infrastructure facilities to be fully utilized for different purposes and are not managed well. It is in this context that attention should be given to protect, conserve and develop the open spaces in order to improve the quality of urban life and livelihood of the local people.

\section{References}

Addas, Adbullah N. (2015). Motivation and attachment in the use of public open spaces in Jeddha, Saudia Arabiya. Unpublished Ph.D. Dissertation, Landscape Department: The University of Sheffield. 
Adhikari, J. (2004). A social ecological analysis of the loss of public's properties in an urban environment: A case study of Pokhara, Nepal. Contribution of Nepalese society, 31(1): 85-114.

Burmill, S., Danial T. C., \& Hetherington J. D. (1999). Human values and perception of water in arid landscape. Landscape and Urban Planning, 44 (2): 99-109.

Campbell, C. S. (1978). Water in landscape architecture. New York: Van Nostrand Reinhold Company.

Carmona, Matthew (2003). Public Places, Urban Spaces: The Dimensions of Urban Design, Architectural press/Elsevier. Jordan Hill Oxford

Crange, G. (1982). The Politics of park design: A history of urban parks in America. USA: The MIT Press, Cambridge, Massachusetts.

Carr, S., Francis, M., Rivlin, L. G., \& Stone, M. (1992). Needs of public space. Cambridge, UK: Cambridge University Press.

CBS. (2011). National population and housing census 2011. Kanthmandu, Nepal: Central Bureau of Statistics, National Planning Commission.

DoT (2016). Nepal Tourism Statistics, 2016. Kathmandu: Department of Tourism.

Goettsch, James (2015). Urban open space - A tower in the park and a park in the tower, Council on the tall Buildings and Urban. http://global.ctbuh.org/resources/ papers/download/2473-urban-open-space-a-tower-in-the-park-and-a-park-inthe-tower.pdf (Accessed 5th November, 2017).

Gold, S. M., (1980). Recreation planning and design. New York: Mc Graw-hill, Book Company, p152.

Green, F. H. W. (1950). Urban hinterland in England and Wales: An analysis of bus services. Geographical Journal, 116: 64-81.

Guo Qiwei, Xiaojian, Chen, \& Yucong Zhu (2015) A study on urban growth boundary delimitation: The case of Baoji, Weinan and Ankang Urban Master Plan. The Open Cybernetics \& Systemics Journal, 9: 1710-1715.

Hamilton, S. Elery (1997). The IUCN guidelines for cave and karst protection, karst and cave management symposium. 13th National Cave Management Symposium Bellingham, Washington.

Kuchelmeister, G. (1998). Urban forestry: Present situation and prospects in the Asia and Pacific region. FAO Asia-Pacific Forestry Sector Outlook Study, FAO Working Paper No: APFSOS/WP/44. Rome: Food and Agriculture Organization of the United Nations. 
Lynch, Kevin (1981). A theory of good city form. Cambridge, MA: MIT Press.

Mahadeo P. D., \& Jayshanker, D.C. (1969). The concept of city region-, an approach with a case study. Indian geographical Journal, 44: 15-22.

Michell, G. (1994). City as cosmogrames: The circular plan of Warangal, Nati. Gorge J. India.

http://www.sciencedirect.com/science/article/pii/S2095263517300262\#bbib33 (Accessed on 30 October 2017).

Monroe C. Beardsley (1982). The aesthetic point of view. Ithaca and London: Cornell University Press.

Moore, G., \& Golledge, R. (eds.), (1996). Environmental knowing: Theories, research and methods. Stroudsburg. PA: Dowden, Hutchinson and Ross. (Retrieved on 4 November 2017).

Popi, P., Sudaryono, A. D., \& Heddy, S.A. P. (2012). Ritual and space structure: Pilgrimage and space use in historical urban kampong context of Luar Batang (Jakarta, Indonesia). Social. Behavioral. Science, 36: 350-360.

Sandlack, B. A., \& Uribe F. G. A (2010). Open space typology as a framework for design of the public realm. The Face of the Urbanized Spaces, 5: 35-61.

Stanley, B. W., Stark, B. L., Johnston, K. L., \& Smith, M. E. (2012). Urban open spaces in historical perspective: A trans-disciplinary typology and analysis. Urban Geography, 33 (8): 1089-1117.

Staeheli, 1., \& Mitchell, D. (2008). The people's property? power, politics, and the public. New York: Routledge.

Ulrich, R. S. (1981). Natural versus urban scenes: Some psychophysiological effects. Environment and Behavior, 13: 523-556.

Wang, D., Metwo-Babiano, I., \& Brown, G. (2007). Rethinking accessibility in planning of urban open space using an integrative theoretical framework. Conference paper submitted to State of Australian Cities.

Wang, G., Jiang, G., Zhou, Y., Liu, Q., Ji, Y., Wang, S., Chen, S., \& Liu, H. (2005). Biodiversity conservation in a fast-growing metropolitan area in China: A case study of plant diversity in Beijing. Biodiversity and Conservation, 16 (14): 4025-4038.

Ward Thompson, C. (2002). Urban open space in the 21st century, landscape and urban planning.http://sites.biology.duke.edu/wilson/EcoSysServices/papers/ Thompson2002.pdf (Accessed on 12 June, 2016). 
Ramjee Prasad Pokharel and Narendra Raj Khanal / The Geographical Journal of Nepal Vol. 11: 25-44, 2018

Woolley, H. (2003). Urban open spaces. London, New York: Spon Press.

Zhang, Z., \& Zhang, S. (2013). The ideas and methods of spatial structure-oriented urban growth boundary delimitation. City PlanningForum, 4: 33-41. 


\section{Annex -1}

Typology and sub typology of open space:

\begin{tabular}{|c|c|c|c|c|}
\hline & $\begin{array}{l}\text { Sub- } \\
\text { Typology }\end{array}$ & $\begin{array}{l}\text { Existing } \\
\text { Number }\end{array}$ & Name of major open spaces & Uses \\
\hline \multirow[t]{6}{*}{ Park } & Mini park & 25 & $\begin{array}{l}\text { Annapurna, Balmandir, Bhanu, } \\
\text { Birendra, Dhungesangu, Deep } \\
\text { united, Phewa dem, Phew } \\
\text { powerhouse east and west, Ghari } \\
\text { patan, Ghaneshman, housing } \\
\text { complex, Jalinayak, Kopildhunga, } \\
\text { Kundahar, Milan, Mitteri village, } \\
\text { mother, Patangini, Puspalal, } \\
\text { Sattyaharichandra, School patan, } \\
\text { Seti gorge, Thati, Visit Nepal year. }\end{array}$ & $\begin{array}{l}\text { Recreation, } \\
\text { meeting, } \\
\text { waiting. }\end{array}$ \\
\hline & Green park & 7 & $\begin{array}{l}\text { Bairagi Ban, Banpale, Jaya kot- } \\
\text { Karkindada, Goltaranga, Kodi } \\
\text { Danda, Shantiban, World botanical } \\
\text { garden }\end{array}$ & $\begin{array}{l}\text { Recreation, } \\
\text { picnic, } \\
\text { walking, } \\
\text { Jungle safari }\end{array}$ \\
\hline & $\begin{array}{l}\text { Formal } \\
\text { garden } \\
\text { (park) }\end{array}$ & 4 & $\begin{array}{l}\text { Bangaicha Basundhara Komagane, } \\
\text { Manohar }\end{array}$ & $\begin{array}{l}\text { Recreation, } \\
\text { meeting, } \\
\text { yoga, cultural } \\
\text { activities, } \\
\text { walking }\end{array}$ \\
\hline & $\begin{array}{l}\text { Memorial } \\
\text { park }\end{array}$ & 4 & $\begin{array}{l}\text { Martyrs park-2, Sahid chock, } \\
\text { Vimsen Park }\end{array}$ & $\begin{array}{l}\text { Recreation, } \\
\text { meeting, } \\
\text { walking }\end{array}$ \\
\hline & $\begin{array}{l}\text { Institutional } \\
\text { park }\end{array}$ & 4 & $\begin{array}{l}\text { Camping chock, Harka chock } \\
\text { Mountain Museum, Tutunga, }\end{array}$ & $\begin{array}{l}\text { Camping, } \\
\text { sightseen, } \\
\text { cultural } \\
\text { activities, } \\
\text { economic } \\
\text { activities }\end{array}$ \\
\hline & $\begin{array}{l}\text { Purposed } \\
\text { park }\end{array}$ & 51 & $\begin{array}{l}\text { Lovely hill, Dhwareko Kharbari } \\
\text { Pandit danda etc } \\
\text { (51 Purposed sites). }\end{array}$ & Proposed park \\
\hline
\end{tabular}




\begin{tabular}{|c|c|c|c|c|}
\hline \multirow[t]{5}{*}{ Playground } & $\begin{array}{l}\text { Well } \\
\text { managed }\end{array}$ & 2 & $\begin{array}{l}\text { Golf ground, Pokhara Stadium } \\
\text { (Rangasala) }\end{array}$ & $\begin{array}{l}\text { Indoor and } \\
\text { outdoor } \\
\text { games } \\
\text { national and } \\
\text { international } \\
\text { games }\end{array}$ \\
\hline & Managed & 2 & Bhandardhik, Sahara play ground & $\begin{array}{l}\text { Outdoor } \\
\text { games }\end{array}$ \\
\hline & $\begin{array}{l}\text { Partially } \\
\text { managed }\end{array}$ & 12 & $\begin{array}{l}\text { Ammarsingh ground east, } \\
\text { Ammarsingh ground west, } \\
\text { Gahte, Gaurishankar, Jadevi, } \\
\text { Malepatan, Bharatpokahri, Bamdi, } \\
\text { Rameshwori, Sarang playground, } \\
\text { Tallo pundi, Thundikhelbagar. }\end{array}$ & Games \\
\hline & $\begin{array}{l}\text { Without } \\
\text { management }\end{array}$ & 9 & $\begin{array}{l}\text { Bamdi, Danda Pokhari, Phewa } \\
\text { Powerhouse, Patan Bensi, Simpani, } \\
\text { shyaltara, Uppalo Patan, Yamdi-2 }\end{array}$ & $\begin{array}{l}\text { Occasional } \\
\text { use for } \\
\text { volleyball, } \\
\text { football }\end{array}$ \\
\hline & Adventure & 1 & Sarankot. & $\begin{array}{l}\text { Use for flying } \\
\text { paraglide }\end{array}$ \\
\hline \multirow[t]{3}{*}{$\begin{array}{l}\text { Religious } \\
\text { site }\end{array}$} & $\begin{array}{l}\text { With formal } \\
\text { garden }\end{array}$ & 6 & $\begin{array}{l}\text { Bindhabasini, Dharmasila } \\
\text { Bhuddabihar, Gumba Jayakot, } \\
\text { Radhakrishna Temple, Puskreshwor } \\
\text { Mahadev, Shanti Stupa }\end{array}$ & $\begin{array}{l}\text { Worship, } \\
\text { recreation, } \\
\text { cultural } \\
\text { activities }\end{array}$ \\
\hline & $\begin{array}{l}\text { With green } \\
\text { space }\end{array}$ & 9 & $\begin{array}{l}\text { Bhadrakali, Harhar Gupha, } \\
\text { Ghakristhan, Gupta kalika temple, } \\
\text { Magthum tapoban, Jantikiche } \\
\text { stone, Shidshwor Siva Panchyan, } \\
\text { Shiva Temple, Talbaharai. }\end{array}$ & $\begin{array}{l}\text { Worship, } \\
\text { cultural } \\
\text { activities, } \\
\text { yoga }\end{array}$ \\
\hline & $\begin{array}{l}\text { Open field } \\
\text { only }\end{array}$ & 47 & $\begin{array}{l}\text { Mahaprahbu Dham, Osho Upaban, } \\
\text { Galeshwor Shivalaya etc.(47 } \\
\text { Religious sites) }\end{array}$ & Worship, yoga \\
\hline
\end{tabular}




\begin{tabular}{|c|c|c|c|c|}
\hline \multirow[t]{5}{*}{$\begin{array}{l}\text { Water } \\
\text { Surface }\end{array}$} & $\begin{array}{l}\text { Lakes } \\
\text { popular }\end{array}$ & 3 & Phewa, Begnas Rupa, & $\begin{array}{l}\text { Recreation, } \\
\text { aesthetic } \\
\text { water fun }\end{array}$ \\
\hline & Lakes & 7 & $\begin{array}{l}\text { Deepang, Gunde, Kamal Pokhari, } \\
\text { Kasyap, Khaste, Maidi, Niureni } \\
\text { etc. }\end{array}$ & Water fun \\
\hline & Ponds & 8 & $\begin{array}{l}\text { Bhadrakali, Banjhi Pokahari, } \\
\text { Kalika, Kaure, Khadka, } \\
\text { Maula, Sani Pokhari, Thuli } \\
\text { Pokhari. }\end{array}$ & $\begin{array}{l}\text { Use by local } \\
\text { people }\end{array}$ \\
\hline & Waterfall & 2 & $\begin{array}{l}\text { Devid fall, Phewa powerhouse, } \\
\text { Bijayapur water fall }\end{array}$ & Recreation \\
\hline & Reservoir & 1 & Jaubari & Sightseen \\
\hline \multirow[t]{3}{*}{ Aesthetic } & $\begin{array}{l}\text { Very active } \\
>300 \text { visitors }\end{array}$ & 1 & Sarankot, & $\begin{array}{l}\text { Closed view } \\
\text { of Himalaya } \\
\text { and Pokhara } \\
\text { valley }\end{array}$ \\
\hline & $\begin{array}{l}\text { Active }< \\
300 \text { visitors }\end{array}$ & 8 & $\begin{array}{l}\text { Gharmi, Kahun Danda, Mattikhan, } \\
\text { Phoksing, Pokhara view point, } \\
\text { Pumdikot Sundari, Thulakot, etc. }\end{array}$ & $\begin{array}{l}\text { Surrounding } \\
\text { view and } \\
\text { mountain } \\
\text { views }\end{array}$ \\
\hline & $\begin{array}{l}\text { View point } \\
\text { not well } \\
\text { developed }\end{array}$ & 8 & $\begin{array}{l}\text { Armala, Barpandethum, Begnas, } \\
\text { Bhumdikot, Hundikot, Kauile, } \\
\text { Tamagi, Thamadanda }\end{array}$ & $\begin{array}{l}\text { Surrounding } \\
\text { view }\end{array}$ \\
\hline \multirow[t]{2}{*}{ Cave } & $\begin{array}{l}\text { Popular, } \\
\text { long }>100 \\
\mathrm{~m} .\end{array}$ & 3 & Gupteshwor, Mahendra, Bat cave & $\begin{array}{l}\text { Recreation, } \\
\text { geological } \\
\text { mysterious } \\
\text { picnic, } \\
\text { worship }\end{array}$ \\
\hline & $\begin{array}{l}\text { Less } \\
\text { popular, long } \\
<100 \mathrm{~m} \text {. }\end{array}$ & 7 & $\begin{array}{l}\text { Belghari Birendra Gagham, Hemja, } \\
\text { Phewa Power house, Sita, Tamagi, }\end{array}$ & $\begin{array}{l}\text { Geological } \\
\text { mysterious }\end{array}$ \\
\hline
\end{tabular}




\begin{tabular}{|l|l|r|l|l|}
\hline $\begin{array}{l}\text { River strip } \\
\text { (Corridor) }\end{array}$ & $\begin{array}{l}\text { Recreation } \\
\text { Aesthetic } \\
\text { Religious } \\
\text { and } \\
\text { Cemetery }\end{array}$ & 1 & $\begin{array}{l}\text { Seti river, } \\
\text { Gaighat, Tulasi ghat, Ram Ghat, } \\
\text { Sita Ghat, Dobilla, Thhangekuna, } \\
\text { etc. }\end{array}$ & $\begin{array}{l}\text { Rafting, } \\
\text { swimming, } \\
\text { fishing, rock } \\
\text { climbing, } \\
\text { green belt, } \\
\text { Ghats for holy } \\
\text { bathing and } \\
\text { cemetery }\end{array}$ \\
\hline $\begin{array}{l}\text { Messy } \\
\text { places }\end{array}$ & Wet land & 8 & $\begin{array}{l}\text { Phew, Begnas, Gunde, Khaste, } \\
\text { Niureni, Rupa, Kamlapokhari, } \\
\text { Lakes side, }\end{array}$ & Biodiversity \\
\cline { 2 - 6 } & $\begin{array}{l}\text { Site for } \\
\text { exhibition }\end{array}$ & 1 & $\begin{array}{l}\text { Pardarsani Kendra ( Exhibition } \\
\text { center) }\end{array}$ & $\begin{array}{l}\text { Business } \\
\text { and cultural } \\
\text { activities }\end{array}$ \\
\cline { 2 - 5 } & $\begin{array}{l}\text { Dumping } \\
\text { site }\end{array}$ & 1 & Ward no 14, Bacchebududwa & $\begin{array}{l}\text { Dumping of } \\
\text { urban wastes }\end{array}$ \\
\cline { 2 - 6 } & Others & 5 & $\begin{array}{l}\text { Karki Danda, Phewa Power house, } \\
\text { Dobilla, Begnas lake, Kalikhola. }\end{array}$ & Picnic site \\
\hline
\end{tabular}

